\title{
Graptemys pulchra Baur 1893 - Alabama Map Turtle
}

\author{
JefFrey E. Lovich ${ }^{1}$, JAMes C. Godwin ${ }^{2}$, AND C.J. MCCOY ${ }^{3}$ \\ ${ }^{1}$ U.S. Geological Survey, Southwest Biological Science Center, \\ 2255 North Gemini Drive MS-9394,_Flagstaff, Arizona 86001 USA [jeffrey_lovich@usgs.gov]; \\ ${ }^{2}$ Alabama Natural Heritage Program, Environmental Institute, \\ 1090 S. Donahue Drive, Auburn University, Alabama 36849 USA [jcg0001@auburn.edu]; \\ ${ }^{3}$ Deceased; formerly Carnegie Museum of Natural History, \\ 4400 Forbes Ave., Pittsburgh, Pennsylvania 15213 USA
}

Summary. - The Alabama Map Turtle, Graptemys pulchra (Family Emydidae), is a moderately large riverine species endemic to the Mobile Bay drainage system of Alabama, Georgia, and Mississippi. Sexual size dimorphism is pronounced, with adult females (carapace length [CL] to $273 \mathbf{~ m m}$ ) attaining more than twice the size of adult males (CL to $117 \mathrm{~mm}$ ). The species is an inhabitant of relatively large, swift creeks and rivers, often with wide sandbars. Stream sections open to the sun and with abundant basking sites in the form of logs and brush are preferred. Six to seven clutches of 4-7 eggs are laid each year on river sandbars. Although the species is locally abundant, populations are threatened by habitat destruction, declines in their prey base, commercial collection, and vandalism. It is listed as a Species of Special Concern in Alabama.

Distribution. - USA. Restricted to the Mobile Bay drainage system of Alabama, northwestern Georgia, and northeastern Mississippi.

Synonymy. - Graptemys pulchra Baur 1893, Malacoclemmys pulchra, Malaclemys lesueurii pulchra, Malaclemys pulchra, Graptemys pulchra pulchra.

SubSPECIES. - None currently recognized.

STATUS. - IUCN 2013 Red List Status: Near Threatened (NT, assessed 2011); CITES: Appendix III (all Graptemys spp.; USA); US ESA: Not Listed; Alabama Department of Conservation and Natural Resources: protected under Nongame Species Regulation; Georgia Department of Natural Resources legal status: Rare; Mississippi: no protection.

Taxonomy. - The Alabama Map Turtle was described in 1893 by Baur on the basis of specimens from a lake near Montgomery, Alabama. The type locality is unusual in that Graptemys pulchra is a riverine species. The species was

essentially "lost" until 1949 when it was rediscovered and redescribed by Cagle (1952). As originally described, $G$. pulchra had the most extensive range of any species of Graptemys on the Gulf Coast (excluding species in the

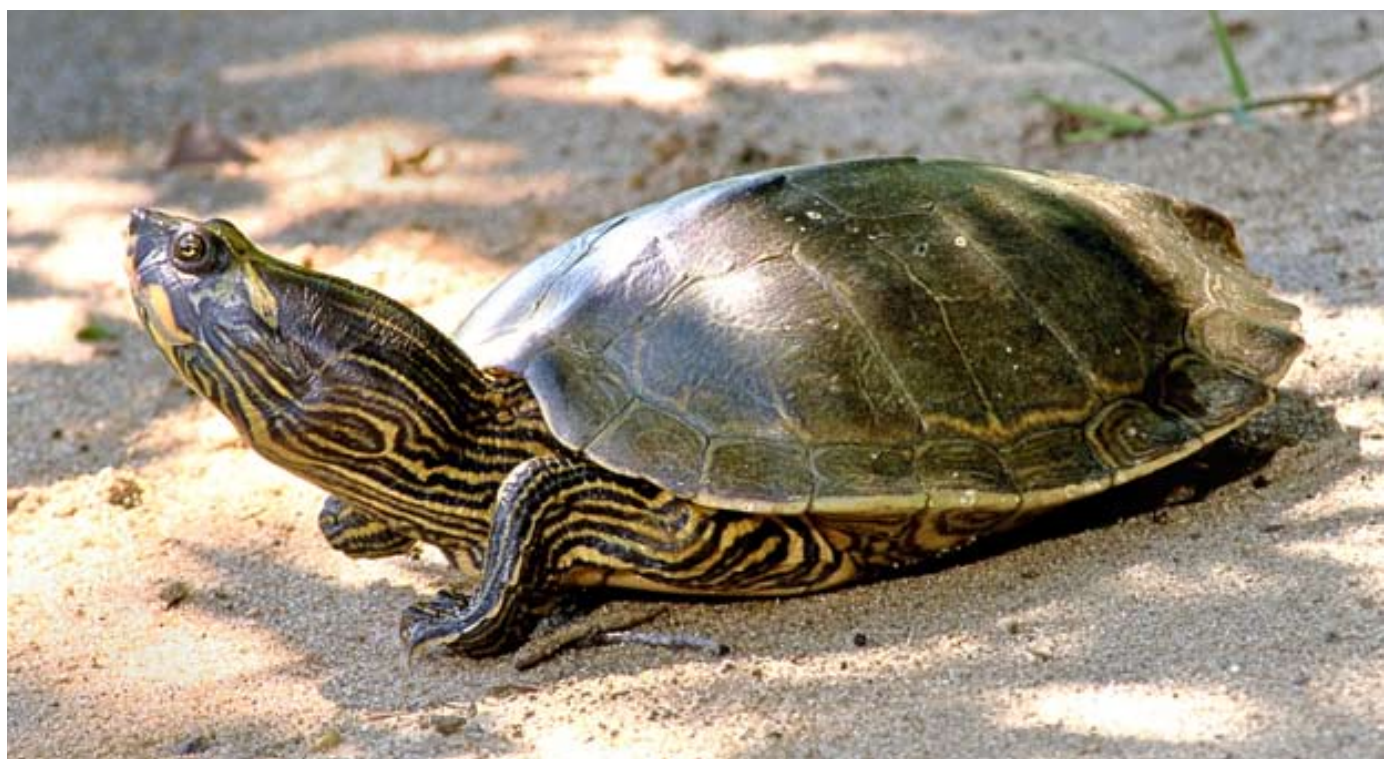

Figure 1. Adult female Graptemys pulchra from the lower Tallapoosa River, Elmore County, Alabama. Photo by James C. Godwin. 




Figure 2. Small female Graptemys pulchra in which the head and jaw have not achieved maximum width. Photo by James C. Godwin.

Mississippi River system). Lovich and McCoy (1992) demonstrated that G. pulchra (sensu lato) was composed of three distinct species, each confined to a single or two closely associated drainage systems: G. pulchra of the Mobile Bay drainage system, Graptemys ernsti (Lovich and McCoy 1994a) of the Escambia Bay drainage system, and Graptemys gibbonsi (Lovich and McCoy 1994b; Lovich et al. 2009) of the Pearl and Pascagoula rivers. Later, Pearl River populations of G. gibbonsi were recognized as distinct and described as Graptemys pearlensis (Ennen et al. 2010). The various species are well-differentiated on the basis of morphology and pattern, and exhibit different mitochondrial DNA haplotypes (Lamb et al. 1994). These four species, together with Graptemys barbouri, form the G. pulchra species group of the genus (Lovich and McCoy 1992). Additional information on G. pulchra (sensu lato) was summarized by Lovich (1985).

Description. - Female Alabama Map Turtles are large (carapace length [CL] to $273 \mathrm{~mm}$ ) while males are much smaller (CL to $117 \mathrm{~mm}$ ). The shell is moderately domed,



Figure 3. Plastron pattern and view of ventral chin and neck pattern of small female Graptemys pulchra. Megacephalic structure and notable jaw width is evident. Photo by James C. Godwin. possesses a median keel, and has concentric yellow markings on the dorsal surface of each marginal scute. The keel is composed of laterally compressed spines that are most salient on the posterior portions of the second and third vertebral


Figure 4. Above: a clutch of Graptemys pulchra hatched from eggs collected from a sandbar along the lower Tallapoosa River, Elmore County, Alabama. Below: an individual G. pulchra hatchling. Note the characteristic connection of the inter-orbital blotch with the postorbital blotches. Photos by James C. Godwin. 


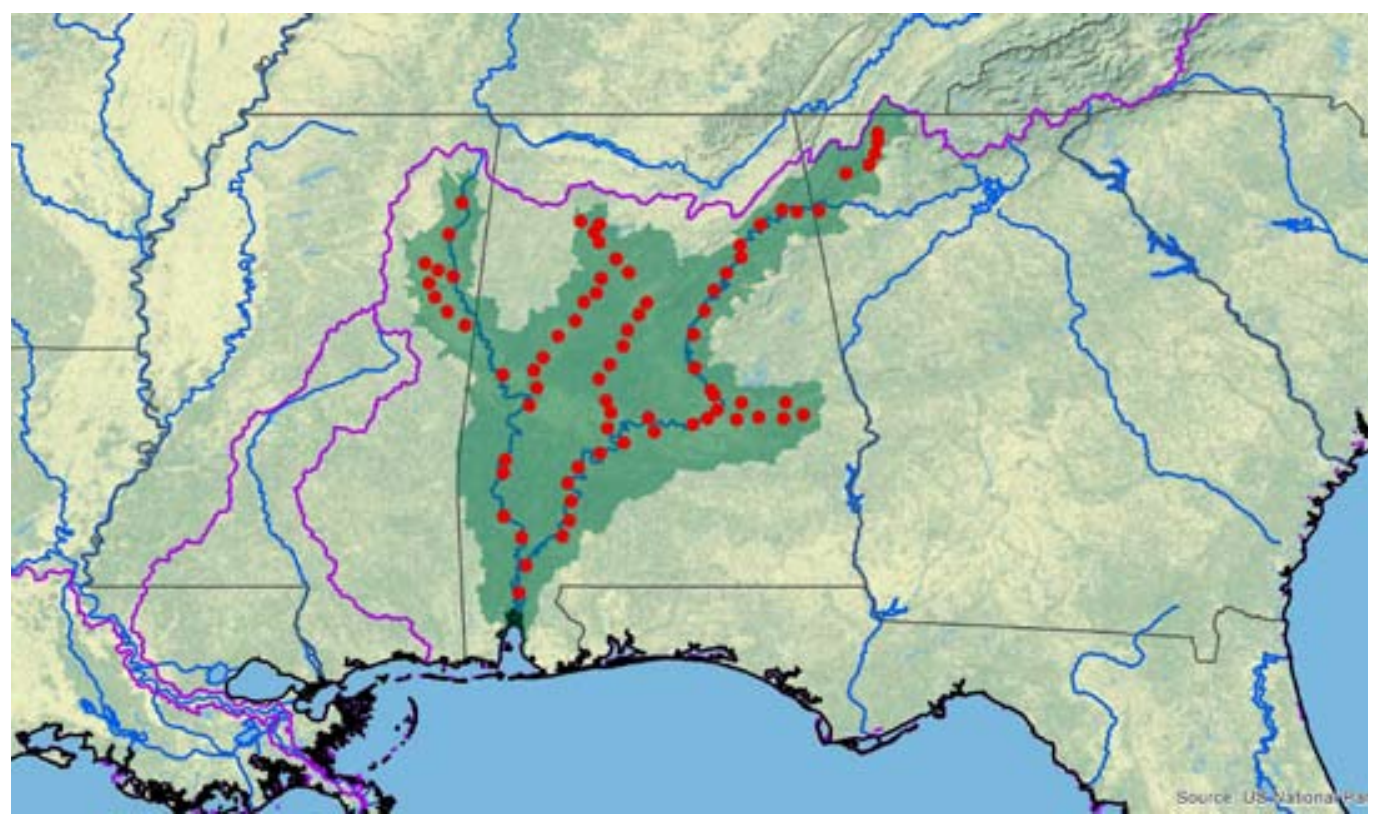

Figure 5. Distribution of Graptemys pulchra in Mississippi, Alabama, and Georgia in southeastern USA. Purple lines = boundaries delimiting major watersheds (level 3 hydrologic unit compartments - HUCs); red dots = museum and literature occurrence records of native populations based on Iverson (1992), plus more recent and authors' data; green shading = projected native distribution based on GIS-defined HUCs constructed around verified localities and then adding HUCs that connect known point localities in the same watershed or physiographic region, and similar habitats and elevations as verified HUCs (Buhlmann et al. 2009), and adjusted based on authors' subsequent data as well as new locality data from Lindeman (2013).

scutes. A black, often interrupted, median stripe divides the dark olive carapace, and narrow yellow vermiculations are present on each pleural scute. The hingeless, pale yellow plastron is characterized by seam-following, and occasionally isolated, areas of dark pigment. Each marginal has wide concentric dark rings on the ventral surface. The skin is brown to olive with light yellow or yellowish-green stripes and blotches. The head pattern resembles a mask, with a large interorbital blotch broadly fused to a pair of relatively narrow postorbital blotches.

In addition to being over twice the length of mature males (Gibbons and Lovich 1990), females have conspicuously enlarged heads with broad jaw surfaces. Males have longer tails with the vent posterior to the rim of the carapace. Both sexes have relatively flat plastrons.

McKown (1972) reported that G. pulchra (sensu lato) possesses 26 macrochromosomes, with 48 arms, and 26 microchromosomes, with 26 arms.

Allopatric, but similar, species differ as follows: $G$. ernsti has an interorbital blotch that is not connected to the postorbital blotches, G. gibbonsi and G. pearlensis have a single wide bar of yellow pigment on each marginal, and $G$. barbouri has a narrow interorbital blotch that ends anteriorly in a narrow point, a curved or transverse bar under the chin and, in small specimens, a conspicuous bump on each of the anterior pleural scutes (Ernst et al. 1994; Ernst and Lovich 2009). In the skull of G. pulchra the vomer extends posteriorly as far as the foramen palatinum posterius; whereas in G. barbouri the posterior edge of the vomer is anterior to the foramen palatinum posterius (Dobie 1981).
Distribution. - The Alabama Map Turtle is restricted to the Mobile Bay drainage system in Alabama, Georgia (Harris et al. 1982), and Mississippi (Thomas and Bradford 1997). Specimens have been collected or observed in the Alabama, Black Warrior, Cahaba, Tombigbee, Coosa, and Warrior rivers, but it is apparently absent from the Tallapoosa River in Alabama above the Fall Line (Mount 1975; Godwin 2003). Numerous smaller tributaries of these major river systems are also home to the Alabama Map Turtle and are listed by Lindeman (2013).

Habitat and Ecology. - The Alabama Map Turtle is an inhabitant of relatively large, swift creeks and rivers, often with wide sandbars. Stream sections open to the sun and with abundant basking sites in the form of logs and brush are preferred. In rocky Cumberland Plateau habitats males are usually found in shallow stretches (often in association with Sternotherus depressus and Apalone spinifera), while females seem to be restricted to deep pools or impoundments (Carl Ernst, pers. obs.).

The introduced Asian clam Corbicula fluminea may be an important source of food for this species, particularly of the females (Marion 1986; Ernst, pers. obs.). McCoy and Vogt (pers. comm.) found that G. pulchra in the Cahaba River of Alabama ate insects (63\%) and vegetation $(33 \%)$.

The species is primarily diurnal, and is active from late March to November (although warm winters may stimulate activity in all months). It is extremely wary when basking, dropping into the water at the first sign of danger. Hatchlings and juveniles bask close to shore in thick brush. Adults typi- 
cally bask on larger logs or snags over deep water. Little else is known of the behavior of this species.

Mount (1975) reported that nesting activity in G. pulchra (sensu lato) begins in late April or early May, reaches a peak in June, and continues through July and August. Six to seven clutches of 4-6 eggs are laid each year on river sandbars, although Lindeman (2013) reported clutch sizes of up to 7 eggs. Nesting was observed on the lower Tallapoosa River on 5 and 21 May and the clutch size of two nests was four and five eggs. Mean egg length and width
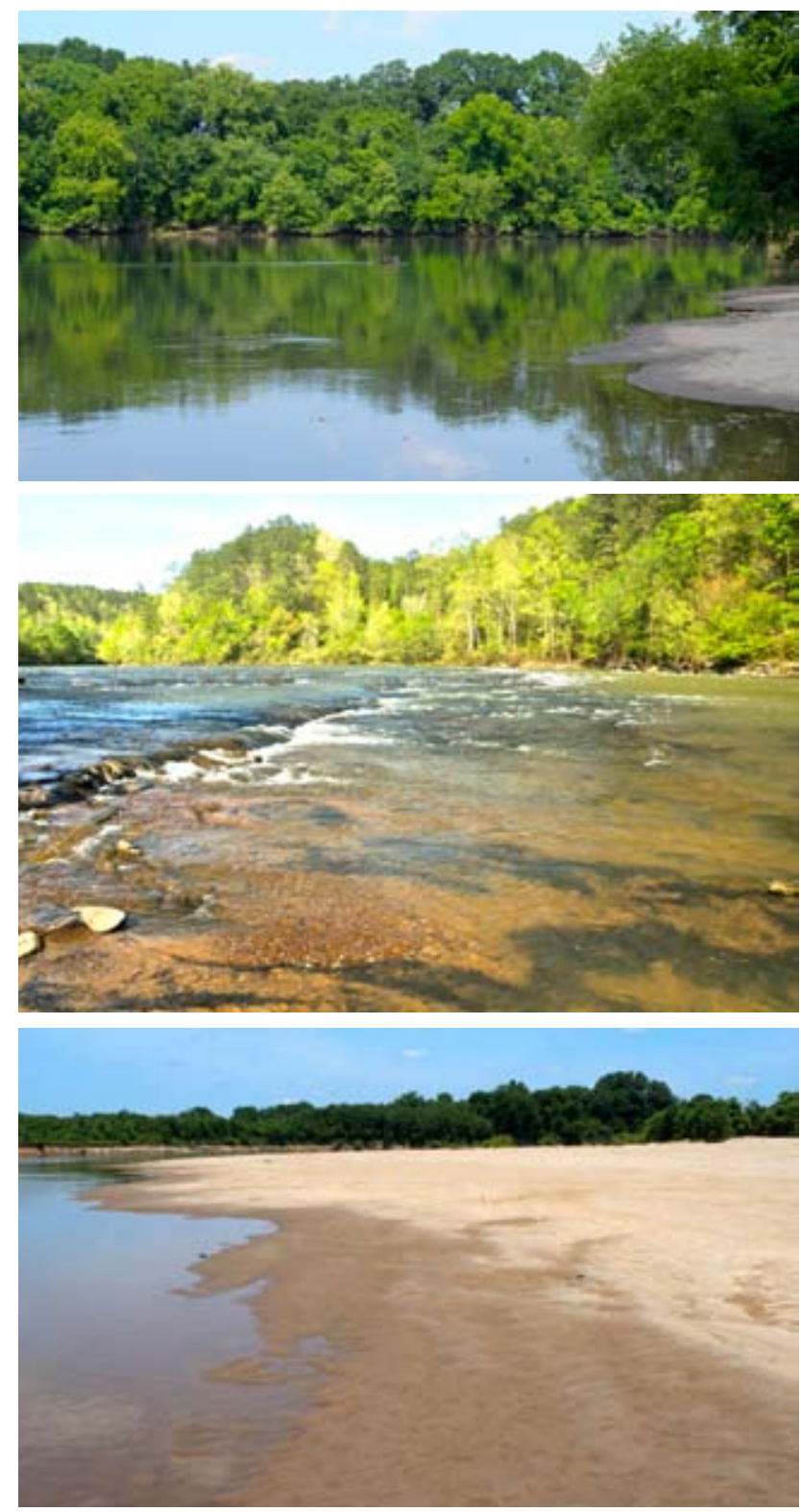

Figure 6. Upper: characteristic coastal plain riverine habitat of Graptemys pulchra with hardwood riparian forests, exposed sandbars, and abundant bask sites. Site is lower Tallapoosa River, Elmore County, Alabama. Middle: upland riverine habitat of G. pulchra at Cahaba River, Bibb County, Alabama. The Alabama Map Turtle is the only megacephalic species with a distribution that crosses the Fall Line. All other megacephalic species have strictly coastal plain distributions. Lower: sandbar along the lower Tallapoosa River, Elmore County, Alabama used for nesting by G. pulchra and $G$. nigrinoda. Photos by James C. Godwin. of the 4-egg clutch were 42.5 and $25.7 \mathrm{~mm}$, respectively. The clutch of five freshly laid eggs, laid on 21 May, was collected and incubated under shaded, ambient, outside air temperatures, hatching after 77 days on 6 August. Mean CL for the five hatchlings was $36.5 \mathrm{~mm}$ and mean mass was 10.9 g (Godwin, unpubl. data). Hatchlings have been collected along the Cahaba River in October (Lovich, pers. obs.). In captivity, nesting has been observed from 21 December -22 June (Goode 1997), but it is not known if this represented G. pulchra (sensu lato) or G. pulchra (sensu stricto). Many nests are destroyed by predators.

The Alabama Map Turtle is sympatric with two other congeneric species: G. geographica in the northern part of the range and G. nigrinoda in the southern part of the range. All three species co-occur in the Cahaba River immediately above the Fall Line, having been observed on the Cahaba River National Wildlife Refuge in Bibb County (Godwin 2010). In the rivers of Alabama, G. pulchra is often seen basking with $G$. nigrinoda, Pseudemys concinna, Trachemys scripta, and Apalone spinifera.

Population Status. - No published information is available on the population status of this species. It is locally abundant in several parts of its range. Tinkle (1959) noted G. pulchra in apparently equal abundance on both sides of the Fall Line in some drainage systems. Godwin (2003) tallied a mean of 1.8 basking turtles per river km below the Fall Line and 4.5 turtles per river km above the Fall Line, notably divergent from Tinkle's previous assessment. The overall mean number of turtles per river $\mathrm{km}$ of the 2003 survey (Godwin 2003) was 2.7. Rivers surveyed included the Alabama (2.4 G. pulchra/km), Black Warrior (0.1 G. pulchra $/ \mathrm{km})$, Cahaba (1.5 G. pulchra/km), Coosa (4.7 G. pulchra/km), Tallapoosa (2.6 G. pulchra/km), Tensaw (0.1 G. pulchra/km), and Tombigbee (0.2 G. pulchra/km).

Threats to Survival. - Habitat degradation and/or destruction are the greatest threats to populations of G.pulchra.

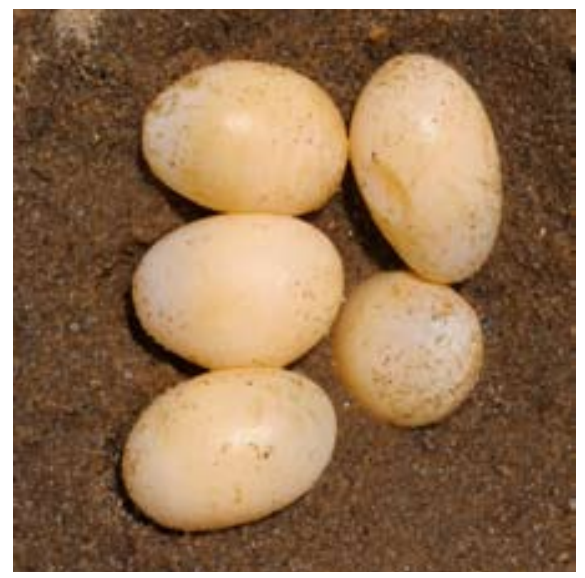

Figure 7. Aclutch of five freshly laid and excavated eggs of Graptemys pulchra from the lower Tallapoosa River, Elmore County, Alabama. All eggs are elongate; lower right egg is partially embedded, thus appearing round. Indentation in upper right egg is due to handling. Photo by James C. Godwin. 
In the northern part of its range, strip mining for coal has resulted in significant habitat modifications that are known to be detrimental to another sympatric turtle, Sternotherus depressus (Dodd et al. 1988; Dodd 1990). The response of G. pulchra to these habitat alterations is unknown. Stream channelization, particularly in the Tombigbee River, and removal of snags, has destroyed habitat in other areas (Lindeman 1999). Impoundment of rivers affects the food base of riverine turtles, especially dietary specialists (Tucker et al.2012), and probably produces habitat unsuitable for those species, although individuals may survive in lakes.

Natural hydrology of rivers and streams within the range of $G$. pulchra has been altered by the construction of at least 26 dams. Hydrological alteration may not have had a direct impact upon populations of G. pulchra but has acted indirectly as the molluscan prey of females have declined. Historically, 71 species of freshwater mussels were found within the range of G. pulchra. Currently only 29 of these mussel species are considered to have stable populations, whereas 34 have undergone population reductions and 8 are extinct or extirpated (Williams et al. 2008).

Although not as colorful as other species of Graptemys, hatchlings and juveniles of G. pulchra are popular in the pet trade. Another range-wide threat to this species is target practice since some unethical sportsmen enjoy shooting at basking turtles (Marion 1986).

Conservation Measures Taken. - The Alabama Map Turtle is classified as a Species of Special Concern in the state of Alabama. This classification is founded on the premise that the species "...must be continually monitored because of imminent threats to the habitat, limited range in Alabama, or because of other physical or biological factors that may cause them to become threatened or endangered within the state in the foreseeable future" (Marion 1986). Godwin (2003) performed a basking survey of G. pulchra throughout much of the Mobile River basin, but this represents only one survey regarding the abundance of the species.

The IUCN Red List (www.iucnredlist.org) assessed the species as Near Threatened in 2011. All Graptemys spp. have been listed on Appendix III of CITES by the USA since 2006. The species occurs in the following protected areas: Bankhead National Forest, Cahaba River National Wildlife Refuge, Choctaw National Wildlife Refuge, Haines Island Park (USACOE), Talladega National Forest (Oakmulgee District), and Upper Delta Wildlife Management Area (ADCNR).

Conservation Measures Proposed. - Marion (1986) suggested several conservation measures for the Alabama Map Turtle, including protecting and improving the water quality of rivers and streams occupied by this species, discouraging stream channelization and removal of snags, prohibiting or further regulating commercial collecting, and monitoring densities of existing populations. In 2000, the Recovery Plan for the Mobile River Basin Aquatic Ecosystem was approved (U.S. Fish and Wildlife Service 2000), encompassing 39 aquatic species. While G. pulchra is not specifically addressed within the plan, a majority of the species included are mussels and snails, potential prey items for G. pulchra. Range-wide status surveys such as the one conducted by Godwin (2003) should be repeated to monitor population trends.

Captive Husbandry. - Most species of Graptemys do well in captivity (Wahlquist 1970; George 1990). Captive males will eat fresh fish, snails, shrimp, trout chow, and occasionally lettuce. In one large private collection in Georgia, captives courted and reproduced regularly (Al Redmond, pers. comm.). Graptemys pulchra (sensu lato) has lived in captivity for over 15 years, even one collected as an adult (Bowler 1977; Slavens and Slavens 2000).

Current Research. - Virtually nothing is known of the ecology of G. pulchra (sensu stricto) and it is ranked 39th out of 58 species as one of the most poorly-studied turtles in the USA (Lovich and Ennen 2013). Research is needed in all areas.

Acknowledgments. - Thanks to James Dobie, Harold Dundee, CarlErnst, Steve Gotte, Craig Guyer, Robert Mount, Steve Rogers, George Zug and others for providing access to museum specimens of G. pulchra early in our studies of this species. Earlier versions of this manuscript benefited from comments offered by John Iverson and Peter Lindeman. The Alabama Department of Conservation and Natural Resources provided funding for studies of the species in Alabama.

\section{LITERATURE CITED}

BAur, G. 1893. Two new species of North American Testudinata. American Naturalist 27(319):675-677.

BowLER, J.K. 1977. Longevity of reptiles and amphibians in North American collections as of 1 November, 1975. Society for the Study of Amphibians and Reptiles, Miscellaneous Publications, Herpetological Circular No. 6.

Buhlmann, K.A., Akre, T.S.B., Iverson, J.B., Karapatakis, D., Mittermeier, R.A., Georges, A., Rhodin, A.G.J., van DiJk, P.P., AND GibBons, J.W. 2009. A global analysis of tortoise and freshwater turtle distributions with identification of priority conservation areas. Chelonian Conservation and Biology 8(2):116-149.

CAGLE,F.R. 1952. The status of the turtles Graptemys pulchra Baur and Graptemys barbouri Carr and Marchand, with notes on their natural history. Copeia 1952(4):223-234.

DobIE, J.L. 1981. The taxonomic relationship between Malaclemys Gray, 1844 and Graptemys Agassiz, 1857 (Testudines: Emydidae). Tulane Studies in Zoology and Botany 23:85-102.

DodD, C.K., JR. 1990. Effects of habitat fragmentation on a streamdwelling species, the flattened musk turtle Sternotherus depressus. Biological Conservation 54:33-45.

Dodd, C.K., JR., Enge, K.M., And Stuart, J.N. 1988. Aspects of the biology of the flattened musk turtle, Sternotherus depressus in northern Alabama. Bulletin of the Florida State Museum, 
Biological Sciences 34(1):1-64.

Ennen, J.R., Lovich, J.E., Kreiser, B.R., Selman, W., and Qualls, C.P.2010.Genetic and morphological variation between populations of the Pascagoula map turtle (Graptemys gibbonsi) in the Pearl and Pascagoula rivers with description of a new species. Chelonian Conservation and Biology 9:98-113.

ERnst, C.H. AND Lovich, J.E. 2009. Turtles of the United States and Canada. Second Edition. Baltimore, MD: John Hopkins University Press, 827 pp.

ERnst, C.H., Lovich, J.E., AND Barbour, R.W. 1994. Turtles of the United States and Canada. Washington, DC: Smithsonian Institution Press, 578 pp.

George, G. 1990. Status and conservation of Graptemys barbouri, Graptemys flavimaculata, Graptemys oculifera and Graptemys caglei.In: Beaman,K.R.,Caporaso,F., McKeown,S., and Graff, M.D. (Eds.). Proceedings of the First International Symposium on Turtles and Tortoises: Conservation and Captive Husbandry. California Turtle and Tortoise Club, Chapman University, pp. 24-30.

GibBons, J.W. ANd Lovich, J.E. 1990. Sexual dimorphism in turtles with emphasis on the slider turtle (Trachemys scripta). Herpetological Monographs 4:1-29.

Godwin, J.C. 2003. Alabama Map Turtle (Graptemys pulchra) Status Survey. Report submitted to the Alabama Department of Conservation and Natural Resources, 20 pp.

Godwin,J.C. 2010.Amphibian and Reptile Inventory of the Cahaba River National Wildlife Refuge. Report submitted to the U.S. Fish and Wildlife Service, 127 pp.

Goode, M. 1997. Eggs and clutch production of captive Graptemys. In: Van Abbema, J. (Ed.). Proceedings: Conservation, Restoration, and Management of Tortoises and Turtles - An International Conference. N.Y. Turtle and Tortoise Society, p. 478.

HARRIS, J.L., LAERM, J., AND VITT, L.J. 1982. Graptemys pulchra, Alabama map turtle. Herpetological Review 13(1):24.

Iverson, J.B. 1992. A Revised Checklist with Distribution Maps of the Turtles of the World. Richmond, Indiana: Privately printed, 393 pp.

Lamb, T., Lydeard, C., WaLker, R.B., AND GibBons, J.W. 1994. Molecular systematics of map turtles (Graptemys): a comparison of mitochondrial restriction site versus sequence data. Systematic Biology 43(4):543-559.

LindEMAN, P.V. 1999. Surveys of basking map turtles Graptemys spp. in three river drainages and the importance of deadwood abundance. Biological Conservation 88:33-42.

Lindeman, P.V. 2013. The Map Turtle and Sawback Atlas: Ecology, Evolution, Distribution and Conservation. Norman, OK: University of Oklahoma Press, $460 \mathrm{pp}$.

Lovich, J.E. 1985. Graptemys pulchra Baur. Alabama map turtle. Catalogue of American Amphibians and Reptiles 360.1-360.2.

Lovich, J.E. And EnNEn, J.R. 2013. A quantitative analysis of the state of knowledge of turtles of the United States and Canada. Amphibia-Reptilia. doi:10.1163/15685381-00002860.

Lovich, J.E. And McCoy, C.J. 1992. Review of the Graptemys pulchra group (Reptilia, Testudines, Emydidae), with descriptions of two new species. Annals of the Carnegie Museum
61:293-315.

Lovich, J.E. And McCoy, C.J. 1994a. Graptemys ernsti. Catalogue of American Amphibians and Reptiles 585.1-585.2.

Lovich, J.E. And McCoy, C.J. 1994b. Graptemys gibbonsi. Catalogue of American Amphibians and Reptiles 586.1-586.2.

Lovich, J.E., Selman, W., AND McCoy, C.J. 2009. Graptemys gibbonsi Lovich and McCoy 1992 - Pascagoula map turtle, Pearl River map turtle, Gibbon's map turtle. In: Rhodin, A.G.J., Pritchard, P.C.H., van Dijk, P.P., Saumure, R.A., Buhlmann, K.A., Iverson,J.B., and Mittermeier, R.A.(Eds.). Conservation Biology of Freshwater Turtles and Tortoises: A Compilation Project of the IUCN/SSC Tortoise and Freshwater Turtle Specialist Group. Chelonian Research Monographs No. 5, pp. 029.1-029.8.

Marion, K.R. 1986. Alabama map turtle. In: Mount, R.H. (Ed.). Vertebrate Animals of Alabama in Need of Special Attention. Alabama Agricultural Experiment Station, Auburn University, pp. 50-52.

McKown, R.R. 1972. Phylogenetic relationships within the turtle genera Graptemys and Malaclemys. Ph.D. Dissertation, University of Texas at Austin.

Mount, R.H. 1975. The Reptiles and Amphibians of Alabama. Auburn, AL: Auburn University Agricultural Experiment Station, $347 \mathrm{pp}$.

Slavens, F.L. And Slavens, K. 2000. Reptiles and Amphibians in Captivity. Breeding - Longevity and Inventory, current January 1, 1999. Seattle, WA: Slaveware, $400 \mathrm{pp}$.

THOMAS, R.B. AND BRADFORD, J. 1997.Graptemys pulchra (Alabama map turtle). Geographic Distribution. Herpetological Review 28(4):209.

TinkLE, D.W. 1959. The relation of the fall line to the distribution and abundance of turtles. Copeia 1959(2):167-170.

Tucker, A.D., Guarino, F., And Priest, T.E. 2012. Where lakes were once rivers: contrasts of freshwater turtle diets in dams and rivers of southeastern Queensland. Chelonian Conservation and Biology 11(1):12-23.

U.S. Fish AND WILdLIFE SERVICE. 2000. Mobile River Basin Aquatic Ecosystem Recovery Plan. Atlanta, GA: USFWS, 128 pp.

WAHLQUist, H. 1970. Sawbacks of the Gulf Coast. International Turtle and Tortoise Society Journal 4(4):10-13, 28.

Williams, J.D., Bogan, A.E., And Garner, J.T. 2008. Freshwater Mussels of Alabama and the Mobile Basin in Georgia, Mississippi and Tennessee. Tuscaloosa,AL:The University of Alabama Press, 908 pp.

\section{Citation Format for this Account:}

Lovich, J.E., Godwin, J.C., And McCoy, C.J. 2014. Graptemys pulchra Baur 1893 - Alabama Map Turtle. In: Rhodin, A.G.J., Pritchard, P.C.H., van Dijk, P.P., Saumure, R.A., Buhlmann, K.A., Iverson, J.B., and Mittermeier, R.A. (Eds.). Conservation Biology of Freshwater Turtles and Tortoises: A Compilation Project of the IUCN/SSC Tortoise and Freshwater Turtle Specialist Group. Chelonian Research Monographs No. 5, pp. 072.1-072.6, doi:10.3854/crm.5.072.pulchra.v1.2014, http:// www.iucn-tftsg.org/cbftt/. 